\title{
MENGUKUR LOYALITAS KONSUMEN MELALUI EKUITAS MEREK PADA PRODUK KOSMETIK
}

\author{
Tuti Mulyani ${ }^{1}$, Asep Muhamad Ramdan ${ }^{2}$, Acep Samsudin ${ }^{3}$ \\ Fakultas Ilmu Administrasi dan Humaniora, Universitas Muhammadiyah Sukabumi \\ Email: tutimulya25@ummi.ac.id ${ }^{1}, \underline{\text { amr37ramdan@ummi.ac.id }}{ }^{2}, \underline{\text { acepsamsudin@ }_{\text {ummi.ac.id }}{ }^{3}}$

\section{Intisari} \\ Tujuan dari penelitian ini untuk mengukur seberapa besar pengaruh ekuitas merek \\ terhadap loyalitas konsumen. Variabel pada penelitan ini adalah kesadaran merek (X1), \\ persepsi kualitas (X2), assosiasi merek (X3), loyalitas merek (X4) dan loyalitas konsumen \\ (Y). metode yang digunakan yaitu metode penelitian kuantitatif dengan pendekatan assosiatif \\ dengan melakukan penyebaran kepada 150 responden wanita yang berumur 25-35 tahun. \\ Loyalitas konsumen dipengaruhi oleh ekuitas merek sedangkan yang lainnya dipengaruhi oleh \\ variabel lain yang diteliti dalam penelitian ini. Adanya hubungan antara dimensi Ekuitas \\ Merek terhadap Loyalitas Konsumen. Dari keseluruhan variabel ekuitas merek ada satu \\ variabel yang tidak berpengaruh dan tidak signifikan terhadap loyalitas konsumen yaitu \\ persepsi kualitas dan yang paling berpengaruh terhadap loyalitas konsumen adalah loyalitas \\ merek.
}

Kata Kunci: Ekuitas merek, Kesadaran Merek, Persepsi Kualitas, Assosiasi Merek, Loyalitas Merek, Loyalitas Konsumen

\section{Abstract}

The purpose of this study is to measure how much influence brand equity has on consumer loyalty. The variables in this research are brand awareness (X1), perceived quality $(X 2)$, brand association (X3), brand loyalty (X4) and consumer loyalty (Y). The method used is quantitative research methods with an associative approach by spreading to 150 female respondents aged 25-35 years. Consumer loyalty is influenced by brand equity while others are influenced by other variables examined in this study. There is a relationship between the Brand Equity dimension to Consumer Loyalty. Of the overall brand equity variables, there is one variable that has no effect and is not significant on consumer loyalty, namely perceived quality and the most influential on consumer loyalty is brand loyalty.

Keywords: Brand Equity, Brand Awareness, Quality Perception, Brand Association, Brand Loyalty, Consumer Loyalty

\section{PENDAHULUAN}

Industri kosmetik pada saat ini menjadi peluang bisnis yang sangat menguntungkan, kosmetik menjadi hal yang wajib digunakan oleh kaum wanita baik yang usia muda maupun yang sudah lanjut usia (Amimi \& Suyanto, 2019). Pengguna kosmetik saat ini sudah sangat banyak, untuk mempertahankan konsumen yang sudah ada dan menarik konsumen yang baru perusahaan harus pintar dalam menciptakan inovasi baru agar mampu bersaing dengan kosmetik yang lain (Pijoh, Saerang, \& Maramis, 2019).

Loyalitas Konsumen sangat berperan dalam mempertahankan sebuah perusahaan supaya mampu bersaing dengan produk yang lain, karena Loyalitas Konsumen yang baik bisa mempertahankan konsumen yang lama untuk terus membeli ulang produk dan menarik konsumen yang baru untuk menggunakan produk suatu perusahaan (Darmawangsa \& Ardani, 2015; Dewi, 2018; Francisco, 2013; Ummah, 2019). Banyaknya pilihan merek yang berbeda 
dipasaran mendorong para pengusaha kosmetik untuk lebih unggul dalam bersaing yaitu dengan melalui ekuitas merek yang baik agar dapat merebut pangsa pasar dan mendapatkan banyak keuntungan, karena ekuitas merek yang baik akan menjadikan nilai tambah kepada konsumen untuk melakukan pembelian produk secara berulang dimasa yang akan datang (Studi \& Kim, 2018; Yuliansyah \& Timotius Dwi Handoko, 2019;Aulia, 2019).

Ekuitas merek seringkali dijadikan pembeda oleh konsumen dengan produk yang lain, ekuitas merek dibentuk oleh sebuah produk agar dapat memberikan nilai tambah secara langsung maupun tidak langsung, karena merek yang kuat yaitu merek yang dapat dengan mudah dikenal dipasaran (Raharja \& Aksari, 2019). Dimensi kuitas merek yaitu kesadaran merek, persepsi kualitas, assosiasi merek dan loyalitas merek (Lebriani, 2019;Ramdan, Rahayu, Huriyati, \& Sultan, 2020).

Hal yang mengakibatkan mernurunnya Loyalitas Konsumen yaitu karena banyaknya konsumen yang memiliki kecenderungan memilih menggunakan produk yang baru dan mulai meningalkan produk yang sudah lama digunakan (Anggraini \& Ruzikna, 2015; Bambang \& Heriyanto, 2017; Foster, 2011).

Pada penelitian (R. R. Anggraini, 2019; Erida, Roza, \& Shinta, 2015; Nugroho, 2015; Rianto \& Yunus, 2019; Widyastuti \& Hakim, 2019) menyatakan bahwa ekuitas merek berpengaruh terhadap loyalitas konsumen. Sedangkan dalam penelitian (Hakim \& Purwoko, 2019) menunjukkan bahwa ekuitas merek tidak memiliki pengaruh terhadap Loyalitas konsumen.

Pada penelitian ini yang dijadikan variabel yaitu Kesadaran Merek Persepsi Kualitas, Assosiasi Merek, Loyalitas Merek, dan Loyalitas Konsumen. Berdasarkan latar belakang masalah diatas peneliti tertarik untuk melakukan penelitian yang berjudul "Mengukur

\section{Loyalitas Konsumen melalui Ekuitas Merek pada Produk Kosmetik".}

\section{TINJAUAN PUSTAKA DAN PENGEMBANGAN HIPOTESIS}

\section{Pengaruh Kesadaran Merek (Brand Awareness) terhadap Loyalitas Konsumen}

Kesadaran Merek (Brand Awareness) "kesadaran merek merupakan kesanggupan konsumen dalam menjelaskan dan mengingat merek yang sudah mereka gunakan" (Fahlefi \& Indriastuti, 2019; Trarintya et al., 2019; Sumarwan et al., 2013).

Pada penelitian terdahulu (Garlina, 2014) yang berkaitan dengan kesadaran merek terhadap loyalitas konsumen menyebutkan bahwa kesadaran merek dapat mempengaruhi loyalitas konsumen suatu produk. Hal ini dilihat dari daya ingat konsumen terhadap fitur dan karakteristik produk untuk melakukan pembelian secara berulang dimasa yang akan datang.

$\mathbf{H}_{1}$ : Terdapat pengaruh kesadaran merek terhadap loyalitas konsumen

\section{Pengaruh Persepsi Kualitas (Perceived Quality) terhadap Loyalitas Konsumen}

Pesepsi Kualitas (Perceived Quality) merupakan persepsi yang melekat dalam benak konsumen mengenai keunggulan suatu produk berdasarkan kepentingan dan pengalaman konsumen (Fahlefi \& Indriastuti, 2019; Sumarwan et al., 2013; Trarintya, Sumadi, \& Ayu, 2019; Yuliansyah \& Timotius Dwi Handoko, 2019).

Pada penelitian terdahulu yang dilakukan (R. R. Anggraini, 2019) yang berkaitan dengan persepsi kualitas terhadap loyalitas konsumen menyatakan bahwa kepercayaan yang besar dari pelanggan terhadap kualitas suatu produk dapat meningkatkan loyalitas konsumen terhadap suatu merek. Hal tersebut ditunjukkan dengan kesetiaan konsumen yang tetap membeli produk yang sama meskipun banyak produk pesaing yang sejenis.

$\mathbf{H}_{2}$ : Terdapat pengaruh persepsi kualitas (perceived quality) terhadap loyalitas konsumen 


\section{Pengaruh Assosiasi Merek (Brand Association) terhadap Loyalitas Konsumen}

Assosiasi Merek (Brand Association) merupakan segala informasi yang menyangkut identitas suatu merek yang dijadikan pembeda oleh konsumen untuk melakukan pembelian secara berulang (Laode, 2014; Sumarwan et al., 2013; Trarintya et al., 2019).

Pada penelitian terdahulu (Garlina, 2014) yang berkaitan dengan assosiasi merek terhadap loyalitas konsumen menyatakan bahwa informasi yang jelas dan bermanfaat menyangkut identitas produk berpengaruh terhadap loyalitas konsumen untuk melakukan pembelian secara berulang. Hal ini dilihat dari kepercayaan konsumen mengenai informasi positif yang didapatkan konsumen terhadap suatu merek untuk melakukan pembelian berulang dimasa yang akan datang.

H3: Tredapat pengaruh assosiasi merek terhadap loyalitas konsumen

\section{Pengaruh Loyalitas Merek (Brand Loyalty) terhadap Loyalitas Konsumen}

Loyalitas Merek (Brand Loyalty) merupakan ukuran komitmen konsumen dalam melakukan pembelian produk yang sama secara berulang dimasa sekarang ataupun dimasa yang akan datang (Sudaryono, 2016; Yuliansyah \& Timotius Dwi Handoko, 2019; Fahlefi \& Indriastuti, 2019).

Pada penelitian terdahulu (Erida et al., 2015) yang berkaitan dengan Loyalitas Merek terhadap loyalitas konsumen mengemukkan bahwa loyalitas merek dominan mempengaruhi loyalitas konsumen. Karena konsumen yang loyal akan terus melakukan pembelian terhadap suatu merek walaupun dihadapkan dengan banyak produk pesaing yang sejenis.

H4: Terdapat pengaruh loyalitas merek terhadap loyalitas konsumen

\section{Loyalitas Konsumen}

Loyalitas Konsumen adalah suatu komitmen atau kesetiaan konsumen terhadap suatu merek disertai dengan pembelian berulang tanpa paksaan dari pihak manapun dan suka rela menyarankan kepada orang lain untuk menggunakan dan membeli suatu produk (Priansa, 2017; Putri \& Prasetio, 2019).

Berdasarkan hipotesis diatas model penelitian ini dapat digambarkan sebagai berikut:

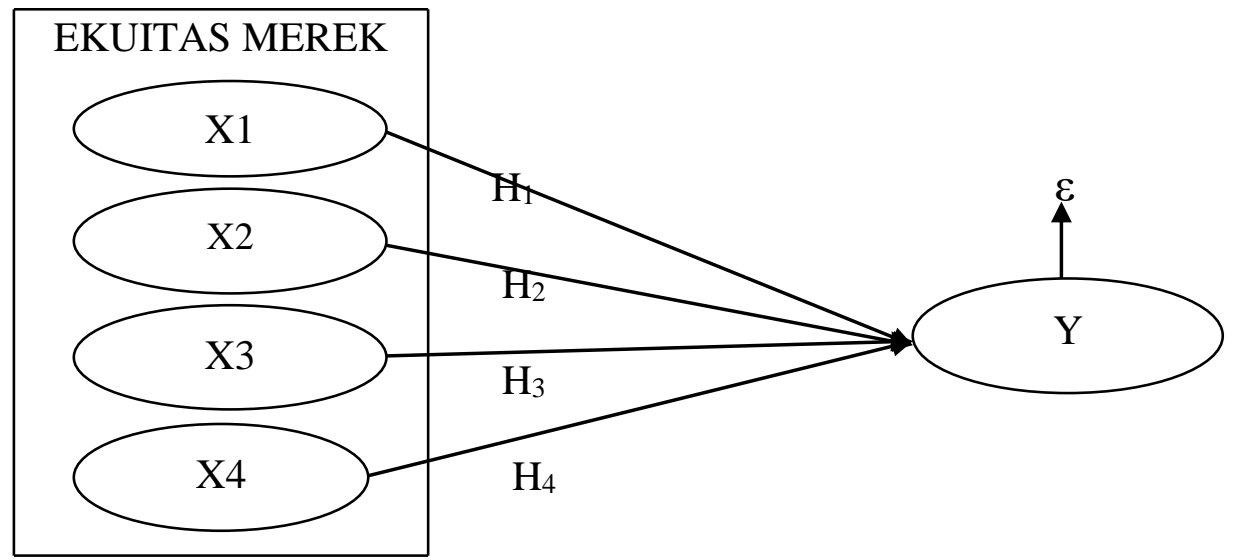

Gambar 1 Paragdigma Penelitian 


\section{METODE PENELITIAN}

Pada penelitian ini dilakukan pada Viva kosmetik Kota Sukabumi yang dikhususkan bagi wanita umur 25-35 tahun. Metode yang digunakan yakni metode Assosiatif dengan menggunakan software IBM SPSS 23. Populasi yang digunakan oleh peneliti yakni wanita umur 25-35 tahun, dengan menggunakan Cluster Sampling dengan melakukan penyebaran kuesioner kepada 150 responden. Teknik analisis data yang digunakan yaitu uji kelayakan model, koefisien determinasi, regresi linear berganda, dan uji hipotesis secara parsial atau uji t. Peneliti akan menjelaskan terlebih dahulu operasional variabel dan indikator pada penelitian ini, yaitu sebagai berikut :

\section{Kesadaran Merek (Brand Awareness)}

Indikator Kesadaran Merek (Brand Awareness) (Trijatmiko et al., 2019; Pulungan, 2019; Akbar, 2019; Ramdan et al., 2020). Yaitu : Unwarre of Brand atau tidak menyadarai merek, Brand Recognition atau pengenalan merek, Brand Recall atau pengingatan kembali merek, Top of Mind atau puncak pikiran, hal yang pertama kali muncul dibenak konsumen.

\section{Persepsi Kualitas (Perceived Quality)}

Indikator Persepsi Kualitas (Perceived Quality) (Laode, 2014; Pulungan, 2019; Yuliansyah \& Timotius Dwi Handoko, 2019; Ramdan et al., 2020) yaitu : Kinerja adalah perlibatan berbagai macam karakteristik utama operasional, Pelayanan merupakan pencerminan kemampuan dalam pemberian pelayanan pada suatu produk, Katahanan adalah perwujudan keawetan suatu produk, Keandalan yaitu konsistensi kinerja dari pembeli pertama ke pembeli selanjutnya, Karakeristik Produk yaitu bagian tambahan dari suatu produk, Kesesuaian Spesifikasi adalah kualitas manufaktur sesuai yang ditentukan, Hasil akhir yang melibatkan 6 dimensi sebelumnya.

\section{Assosiasi Merek (Brand Association)}

Indikator Assosiasi Merek (Brand Association) (Pulungan, 2019; Ramdan et al., 2020) yaitu : Atribut (Attributes) yaitu atribut dari merek-merek tertentu baik yang berhubungan secara langsung ataupun tidak, Manfaat (benefit) yaitu manfaat dari suatu merek baik manfaat fungsional ataupun pengalaman yang dirasakan konsumen, Perilaku (attitude) yaitu motivasi diri sendiri yang merupakan bentuk punishmen, reward, learning, dan knowledge.

\section{Loyalitas Merek (Brand Loyalty)}

Indikator Loyalitas Merek (Brand Loyalty) (Akbar, 2019) yakni :Switcher atau berpindah-pindah merek, Habitual Buyer atau kebiasan pembeli, Satisfied Buyer atau pembeli yang puas, Like the Brand atau menyukai merek, Commited Buyer atau pembeli yang komit.

\section{Loyalitas Konsumen}

Indikator Loyalitas Konsumen mempunyai 4 dimensi (Putri \& Prasetio, 2019) yakni : Melakukan pembelian secara teratur, melakukan pembelian antar lini, mereferensikan kepada orang lain, menunjukan keunggulan terhadap daya tarik produk sejenis dari pesaing. 


\section{HASIL DAN PEMBAHASAN \\ Uji Kelayakan Model}

Untuk mengetahui apakah model yang dianalisis memiliki kelayakan yang tinggi dimana variabel yang diteliti mampu menjelaskan permasalahan yang diteliti. Adapun hasil pengolahan data yaitu sebagai berikut:

Tabel 1 Hasil Uji F

\begin{tabular}{llllll}
\hline \multicolumn{6}{c}{ ANOVA $^{\mathbf{a}}$} \\
\hline Model & & Sum of Square & $d f$ & Mean Square & F \\
\hline 1 & Regression & 1709.955 & 4 & 427.489 & 210.608 \\
\hline & Residual & 294.319 & 145 & 2.030 & \\
\hline & Total & 2004.273 & 149 & & \\
\hline
\end{tabular}

a. Dependent Variable : Loyalitas Konsumen

b. Predictors : (constant), Kesadaran Merek, Persepsi Kualitas, Assosiasi Merek, Loyalitas Merek

Sumber: Data diolah

Hasil Uji $\mathrm{F}$ pada penelitian ini adalah sebesar $\mathrm{F}_{\text {hitung }} 210.608>\mathrm{F}_{\text {tabel }} 2.49$, dapat disimpulkan bahwa hipotesis ini dapat diterima dan dinyatakan layak untuk menjelaskan variabel dependen yang dianalisis karena $F_{\text {hitung }}$ lebih besar daripada $F_{\text {tabel }}$.

\section{Koefisien Determinasi}

Tabel 2 Hasil Koefisien Determinasi

\begin{tabular}{|c|c|c|c|}
\hline \multicolumn{4}{|c|}{ Model Summary } \\
\hline Model & $R$ Square & Adjust $R$ Square & Std. Error of the estimate \\
\hline 1 & $.924^{\mathrm{a}}$ & .849 & 1.42470 \\
\hline
\end{tabular}

Hasil R menunjukkan hasil sebesar 0.924 yang berarti adanya hubungan antara dimensi Ekuitas Merek terhadap Loyalitas Konsumen. Adapun nilai R Square benilai sebesar 0.853 yang berarti bahwa pengaruh dimensi ekuitas merek terhadap loyalitas konsumen sebesar $85.3 \%$ sedangkan sisanya $14.7 \%$ dipengaruhi oleh faktor lain yang tidak diteliti dalam penelitian ini.

\section{Regresi Linear Berganda}

Menurut (Lupiyoadi \& Ikhsan, 2015: 157) menyatakan bahwa Regresi ganda dilakukan oleh peneliti, untuk mengukur hubungan antara dua variabel atau lebih.

Tabel 3 Hasil Regresi Linear Berganda

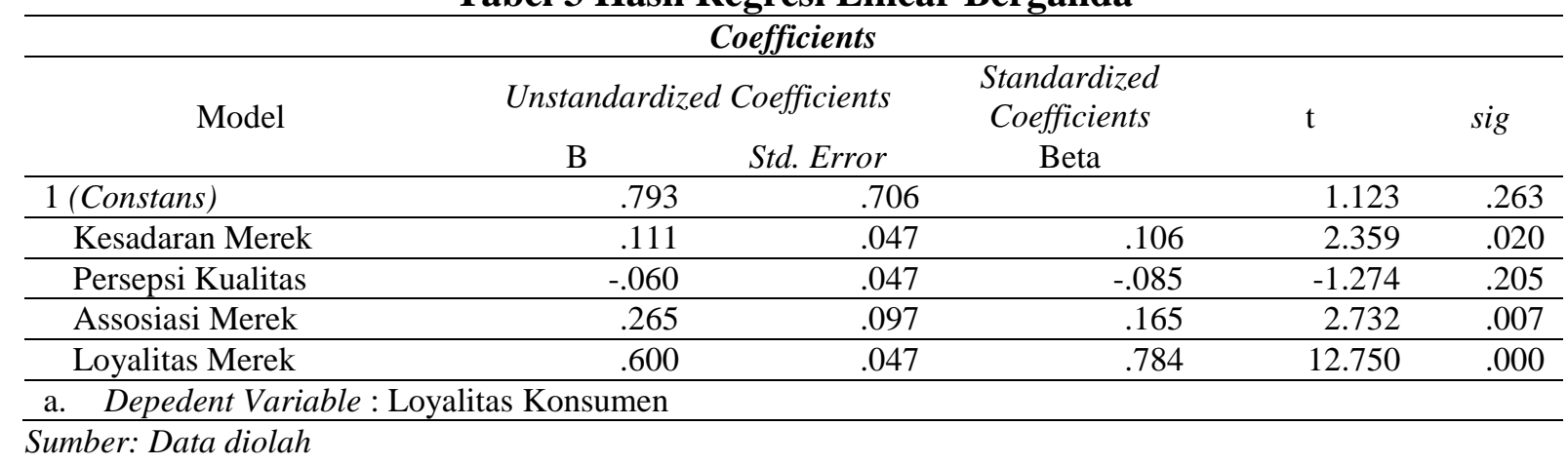


Dari tabel diatas telah didapatkan hasil pengolahan data, dan hasil tersebut dirumuskan sesuai dengan model persamaan regresi linear berganda yaitu sebagi berikut:

$$
\begin{gathered}
Y=a+b_{1} X_{1}+b_{2} X_{2}+b_{3} X_{3}+b_{4} X_{4}+e \\
Y=0.793+0.111 X_{1}+-0.060 X_{2}+0.265 X_{3}+0.600 X_{4}+\varepsilon
\end{gathered}
$$

Konstanta (a) mempunyi nilai sebesar 0.793 yang berarti menunjukkan nilai loyalitas konsumen yaitu sebesar 0.793 .Variabel $\mathrm{X}_{1}$ mempunyai nilai koefisien regresi positif sebesar 0.111, hasil menunjukkan bahwa setiap kenaikan $1 \%$ nilai kesadaran merek maka nilai partisipasi naik 0.111. hal tersebut diartikan bahwa kesadaran merek terhadap Loyalitas Konsumen berpengaruh positif. Variabel $\mathrm{X}_{2}$ mempunyai nilai koefisien regresi negatif sebesar -0.060, hasil menunjukkan bahwa setiap penurunan $1 \%$ nilai kesadaran merek maka nilai partisipasi turun -0.060. hal tersebut diartikan bahwa persepsi kualitas terhadap Loyalitas Konsumen berpengaruh negatif.

Variabel $\mathrm{X}_{3}$ mempunyai nilai koefisien regresi positif sebesar 0.265 , hasil menunjukkan bahwa setiap kenaikan $1 \%$ nilai kesadaran merek maka nilai partisipasi naik 0.265 . hal tersebut diartikan bahwa assosiasi merek terhadap Loyalitas Konsumen berpengaruh positif. Variabel $\mathrm{X}_{4}$ mempunyai nilai koefisien regresi positif sebesar 0.600 , hasil menunjukkan bahwa setiap kenaikan $1 \%$ nilai kesadaran merek maka nilai partisipasi naik 0.600 . hal tersebut diartikan bahwa loyalitas merek terhadap Loyalitas Konsumen berpengaruh positif.

\section{Pengujian Hipotesis secara parsial}

\begin{tabular}{|c|c|c|c|c|c|}
\hline \multicolumn{6}{|c|}{ Coefficients } \\
\hline \multirow[t]{2}{*}{ Model } & \multicolumn{2}{|c|}{ Unstandardized Coefficients } & \multirow{2}{*}{$\begin{array}{c}\text { Standardized } \\
\text { Coefficiets } \\
\text { Beta }\end{array}$} & \multirow[t]{2}{*}{$\mathrm{t}$} & \multirow[t]{2}{*}{ sig } \\
\hline & B & Std. Error & & & \\
\hline 1 (Constans) & .793 & .706 & & 1.123 & .263 \\
\hline Kesadaran Merek & .111 & .047 & .106 & 2.359 & .020 \\
\hline Persepsi Kualitas & -.060 & .047 & -.085 & -1.274 & .205 \\
\hline Assosiasi Merek & .265 & .097 & .165 & 2.732 & .007 \\
\hline Loyalitas Merek & .600 & .047 & .784 & 12.750 & .000 \\
\hline
\end{tabular}

Tabel 4 Uji T

Sumber: Data diolah

Dilihat dari tabel diatas dpat disimpulkan bahwa variabel kesadaran merek hasil $t_{\text {hitung }}$ yaitu sebesar 2.359 dengan nilai signifikansi sebesar 0.020 yang artinya, $\mathrm{H}_{1}$ ada pengaruh positif dan signifikan anatara kesadaran merek terhadap loyalitas konsumen pada produk kosmetik, diterima. Dikarenakan $t_{\text {hitung }}>t_{\text {tabel }}$ yaitu $2.359>1.67$ dengan nilai signifikan 0.020

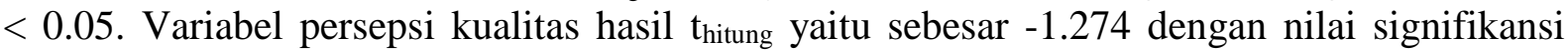
sebesar 0.205 yang artinya, $\mathrm{H}_{2}$ tidak berpengaruh dan tidak signifikan antara persepsi kualitas terhadap loyalitas konsumen pada produk kosmetik, ditolak. Dikarenakan $t_{\text {hitung }}<t_{\text {tabel }}$ yaitu $1.274<1.67$ dengan nilai signifikan $0.205>0.05$. Variabel assosiasi merek hasil thitung yaitu sebesar 2.734 dengan nilai signifikansi sebesar 0.007 yang artinya, $\mathrm{H}_{3}$ ada pengaruh positif dan signifikan anatara assosiasi merek terhadap loyalitas konsumen pada produk kosmetik, diterima. Dikarenakan $t_{\text {hitung }}>t_{\text {tabel }}$ yaitu $2.732>1.67$ dengan nilai signifikan $0.007<0.05$. Variabel loyalitas merek hasil thitung yaitu sebesar 12.750 dengan nilai signifikansi sebesar 0.000 yang artinya, $\mathrm{H}_{4}$ ada pengaruh positif dan signifikan anatara loyalitas merek terhadap 
loyalitas konsumen pada produk kosmetik, diterima. Dikarenakan $t_{\text {hitung }}>t_{\text {tabel }}$ yaitu $12.750<$ 1.67 dengan nilai signifikan $0.007>0.05$.

\section{Pembahasan}

Ada hubungan dimensi Ekuitas Merek terhadap Loyalitas Konsumen pada Produk Kosmetik. Dari keseluruhan dimensi ekuitas merek ada satu variabel yang tidak berpengaruh dan tidak signifikan yaitu persepsi kualitas, hal tersebut dilihat dari hasil pengujian hipotesisi secara parsial atau uji t. Hal ini sejalan dengan hasil penelitian yang dilakukan (Hakim \& Purwoko, 2019) Menunjukkan hasil bahwa ekuitas merek tidak memiliki pengaruh terhadap Loyalitas konsumen. Ekuitas merek merupakan asset yang dapat diperjual belikan nilainya dalam perusahaan karena ekuitas merek merupakan nilai tambah produk yang selalu menjadi pertimbangan konsumen untuk memiliki produk yang akan digunakan.

Ada banyak faktor lain yang dapat meningkatkan loyalitas konsumen pada produk Viva Kosmetik Kota Sukabumi yang dipengaruhi oleh faktor lain yang tidak diteliti dalam penelitian ini.

\section{KESIMPULAN DAN SARAN \\ Kesimpulan}

Dari analisis yang dilakukan, hasil penelitian ini menunjukkan bahwa ekuitas merek sangat berpengaruh penting untuk membentuk loyalitas konsumen pada produk Viva Kosmetik. Dari keseluruhan variabel ekuitas merek ada satu variabel yang tidak berpengaruh dan tidak signifikan terhadap loyalitas konsumen yaitu persepsi kualitas dan yang paling berpengaruh terhadap loyalitas konsumen adalah loyalitas merek.

\section{Saran}

Berdasarkan kesimpulan diatas Viva Kosmetik harus lebih memperhatikan ekuitas merek agar konsumen loyal terhadap produk Viva kosmetik dan tidak beralih menggunakan produk kosmetik yang lain yang baru muncul dipasaran. Untuk penelitian yang akan datang peneliti menyarankan agar menggunakan subvariabel yang lain untuk dijadikan sebagai alat ukur ekuitas merek agar hasil lebih maksimal.

\section{DAFTAR PUSTAKA}

Akbar, M. (2019). Analisis Perbandingan Ekuitas Merek Produk Motor Matic Merek Honda Beat dengan Yamaha Mio ( Studi Kasus pada Konsumen PT . Indako Trading Coy- Sp Limun dengan PT . Yamaha Scorpii Sentral. Universitas Sumater Utara.

Amimi, A. N., \& Suyanto, A. (2019). Analisis Perilaku Konsumen Yang Mempengaruhi Keputusan Pembelian Kosmetik Lokal Di Indonesia Consumer. IEEE International Conference on Acoustics, Speech, and Signal Processing (ICASSP) 2017, 6(1), 84-93.

Anggraini, F., \& Ruzikna. (2015). Pengaruh Brand Image terhadap Loyalitas Pelanggan Pada Koran Harian Riau Pos. Jom Fisip, 3(1), 1-17. https://doi.org/10.1017/CBO9781107415324.004

Anggraini, R. R. (2019). Faktor - Faktor Yang Mempengaruhi Customer Loyalty Pada Konsumen Reksadana Autoinvest Di Bank Commonwealth Jakarta. JIMF (Jurnal Ilmiah Manajemen Forkamma), 2(2), 83-95. https://doi.org/10.32493/frkm.v2i2.3409

Aulia, N. (2019). Tak Hanya Legendaris, 8 Produk Makeup ini Masih Laris dan Eksis. Retrieved from https://beautynesia.id/44234/article/cosmetic/tak-hanya-legendaris-8produk-makeup-ini-masih-laris-dan-eksis

Bambang, A., \& Heriyanto, M. (2017). Pengaruh Brand Equity Dan Brand Trust Terhadap Loyalitas Konsumen Mobil Merek Toyota Kijang Innova. Journal Of Management 
FISIP, 4(2), 1-11.

Darmawangsa, A. A. B., \& Ardani, I. G. A. K. S. (2015). Pengaruh Komunikasi Pemasaran Terpadu dan Ekuitas Merek Terhadap Loyalitas Konsumen. 4(8), 2163-2175.

Dewi, M. (2018). Pengaruh Kepercayaan Merek terhadap Loyalitas Konsumen pada Produk Kosmetik Pixy (Studi Kasus pada Mahasiswi Universitas Samudra). Jurnal Manajemen Dan Keuangan, 6(2), 749-759. https://doi.org/10.33059/jmk.v6i2.681

Erida, Roza, S., \& Shinta. (2015). Pengaruh Ekuitas Merek Terhadap Loyalitas Konsumen Smartphone Samsung Berbasis Android (The influence of Brand on Customer Loyalty of Smartphone Samsung Andorid Basis). 1(1), 58-64.

Fahlefi, D. Ri., \& Indriastuti, A. (2019). Pengaruh Kesadaran Merk, Persepsi Kualitas, Dan Loyalitas Merk Terhadap Keputusan Pembelian Handphone Vivo Pada Angkasa Cell Di Kabupaten Blora. Jurnal Stie Semarang, 11(1), 38-51. https://doi.org/10.33747/stiesmg.v11i1.337

Foster, B. (2011). Pengaruh Kinerja Bauran Penjualan Eceran (Retailing Mix) Dan Hubungan Pelanggan (Customer Relationship) Terhadap Pembentukan Ekuitas Merek, Serta Dampaknya Terhadap Keunggulan Bersaing Dan Loyalitas Pelanggan Department Store Di Dki Jakarta. Strategic: Jurnal Pendidikan Manajemen Bisnis, 10(19), 18-86. https://doi.org/10.17509/strategic.v11i1.1100

Francisco, A. R. L. (2013). Pengaruh Ekuitas Merek Terhadap Loyalitas Konsumen Air Minum Dalam Kemasan Aqua. Journal of Chemical Information and Modeling, 53(9), 1689-1699. https://doi.org/10.1017/CBO9781107415324.004

Garlina, Y. H. (2014). Perbandingan Kulit Moisturizer : Konsumen Berbasis Ekuitas Merek ( Cbbe ) Faktor Dalam Kelompok Berbasis KonsumeN etnosentrisme. 115-122.

Hakim, B. N., \& Purwoko, B. (2019). Strategi Pengembangan Produk Terhadap Loyalitas Pelanggan Melalui Ekuitas Merek Dan Citra Merek. JURNAL EKOBISMAN, 3(3), 261278.

LAODE, F. (2014). Pengaruh ekuitas merek terhadap loyalitas konsumen pada pt. hadji kalla cabang alauddin di makassar.

Lebriani, C. (2019). Analisis Pemetaan Dari Pengukuran Universitas Terakreditasi A Di Kota Bandung Berdasarkan Elemen-Elemen Brand Equity Menggunakan Metode Multidimensional Scaling. Jurnal Manajemen Dan Bisnis Vol., 3(2).

Lupiyoadi, R., \& Ikhsan, R. B. (2015). Praktikum Metode Riset Bisnis. Jakarta: Selemba Empat.

Nugroho, A. P. (2015). Pengaruh Ekuitas Merek Terhadap Loyalitas Konsumen Indomie (Studi Kasus pada Mahasiswa dan Mahasiswi Telkom University di Bandung Tahun 2017). Journal of Chemical Information and Modeling, 53(9), 1689-1699. https://doi.org/10.1017/CBO9781107415324.004

Pijoh, P. P., Saerang, I. S., \& Maramis, J. B. (2019). Pengaruh Diversifikasi Usaha Terhadap Firm Value Pada Sub Sektor Perusahaan Kosmetik Dan Barang Keperluan Rumah Tangga Yang Terdaftar Di Bursa Efek Indonesia Periode 2012-2017. Jurnal EMBA: Jurnal Riset Ekonomi, Manajemen, Bisnis Dan Akuntansi, 7(6), 3259-3268.

Priansa, D. J. (2017). Perilaku Konsumen dalam Persaingan Bisnis Bisnis Kontemporer. Bandung: Alfabeta.

Pulungan, R. (2019). Pengaruh Brand Equity Terhadap Keputusan Pembelian Pada Produk Kecap Manis Abc (Studi Kasus: Supermarket Maju Bersama, Kecamatan Medan Barat, Kota Medan). Universitas Muhammadiya Sumatera Utara Medan.

Putri, A. K., \& Prasetio, A. (2019). Pengaruh Citra Merek Traveloka Terhadap Loyalitas Konsumen. 6(2), 5007-5021. 
Raharja, C. L. M., \& Aksari, N. M. A. (2019). Pengaruh Persepsi Kualitas dan Citra Merek Terhadap Loyalitas Merek Dalam Membangun Ekuitas Merek. E-Jurnal Manajemen, 8(12), 7053-7071. https://doi.org/10.1017/CBO9781107415324.004

Ramdan, A. M., Rahayu, A., Huriyati, R., \& Sultan, M. . (2020). The role of brand equity in making decisions to choose higer education for new midlle-class student. Advances in Business, Management and Enrterpreneurship. Retrieved from https://books.google.co.id/books?hl=id\&lr=\&id=HGXIDwAAQBAJ\&oi=fnd\&pg=PA25 \&ots=BtGOADZMlg\&sig=sN_hPexgIXsuyS_bpZdh4Ne7T4s\&redir_esc=y\#v=onepage $\& \mathrm{q} \& \mathrm{f}=$ false

Rianto, A., \& Yunus, M. (2019). Pengaruh Ekuitas Merek, Nilai Dan Relasional Terhadap Loyalitas Konsumen Swalayan Di Kota Banda Aceh. 4(1), 306-318.

Studi, Y., \& Kim, R. B. (2018). Pengaruh negara asal pada konsumen berbasis ekuitas merek ( $C B B E$ ) dari konsumen Kolombia: Sebuah investigasi empiris dari Samsung vs merek Huawei. 11, 70-81.

Sudaryono. (2016). Manajemen Pemasaran Teori dan Implementasi. Yogyakarta: C.V ANDI OFFSET.

Sumarwan, U., Fachroji, A., Nursal, A., Nugroho, A., Nurzal, E. R., Setiadi, I. A., ... Alamsyah, Z. (2013). Pemasaran Strategik Perspektif Value-Based Marketing \& Pegukuran Kinerja (cetakan 3). Bogor: IPB Press.

Trarintya, N. L. A. A. W., Sumadi, N. K., \& Ayu, M. (2019). Analisis Penilaian Konsumen Pada Ekuitas Merek Produk Herbal Ayurweda Pada Konsumen Di Kota Denpasar. 1(2), 90-112.

Trijatmiko, A., Arifin, Z., \& Fanani, D. (2019). Pengaruh Ekuitas Merek Terhadap Keputusan Pembelian (Survei pada Ibu Rumah Tangga yang Membeli Teh Celup SariWangi di RW 02 Kelurahan Polehan Kecamatan Blimbing Kota Malang). 72(1), 4654.

Ummah, N. N. (2019). Pengaruh Ekuitas Merek Terhadap Loyalitas Konsumen Kosmetik Wardah Dijamber. Jamber.

Widyastuti, S., \& Hakim, B. N. (2019). Model hubungan ekuitas merek, perceived quality dan loyalitas konsumen. Jurnal Forum Ekonomi, 21(1), 45-52.

Yuliansyah, A., \& Timotius Dwi Handoko. (2019). Pengaruh Perceived Quality Dan Perceived Value Terhadap Brand Loyalty Melalui Customer Satisfaction J-Klin Beauty Jember. Duke Law Journal, 1(1), 1-13. https://doi.org/10.1017/CBO9781107415324.004 